\title{
Antioxidant activity of NSAID hydroxamic acids
}

\author{
MARIJANA ZOVKO KONČIĆ* \\ ZRINKA RAJIĆ \\ NEVA PETRIĆ \\ BRANKA ZORC
}

Faculty of Pharmacy and Biochemistry University of Zagreb, Zagreb, Croatia
In the present study, seven hydroxamic acid derivatives of nonsteroidal anti-inflammatory drugs (NSAIDs) (ibuprofen, fenoprofen, ketoprofen, indomethacin and diclofenac) were found to possess significant antioxidant, radical scavenging and metal chelating activities. The most active antioxidant and radical scavenger was $\mathrm{N}$-methylhydroxamic acid of diclofenac $\left(A N T=88.0 \%\right.$ and $E C_{50}=$ $60.1 \mu \mathrm{g} \mathrm{mL}^{-1}$ ). The activity of the standard substance, butylated hydroxyanisole, in the two assays was $A N T=$ $86.9 \%$ and $E C_{50}=18.8 \mu \mathrm{g} \mathrm{mL}^{-1}$, respectively. Ibuproxam was the strongest iron chelator among investigated hydroxamic acids $\left(E C_{50}=255.6 \mu \mathrm{g} \mathrm{mL}^{-1}\right)$, yet significantly weaker than the standard substance, EDTA $\left(E C_{50}=29.1\right.$ $\left.\mu \mathrm{g} \mathrm{mL}{ }^{-1}\right)$. It seems that different mechanism is involved in metal chelating activity than in antioxidant and radical scavenging activity. Antioxidant and radical scavenging activities may be connected with conjugation of the nitrogen lone electron pair with the carbonyl group. On the other hand, more hydrophilic substances tend to be better iron chelators.

Keywords: NSAID, hydroxamic acid, antioxidant activity, radical scavenging activity, metal chelating ability

Reactive oxygen species (ROS), along with reactive nitrogen species (RNS), may play an important role in the pathogenesis and progressing of many diseases. The cumulative production of ROS/RNS through either endogenous or exogenous insults is termed oxidative stress and is responsible for or contributes to many pathological conditions (1). For example, inflammatory tissue injuries are mediated by reactive oxygen metabolites from phagocytic leukocytes (e.g., neutrophils, monocytes, macrophages, and eosinophils) that invade the tissue. These reactive radicals and oxidants may injure cells and tissue directly via oxidative degradation of essential cellular components or indirectly by altering the protease/antiprotease balance that normally exists within the intestinal tissue (2).

\footnotetext{
* Correspondence; e-mail: mzovko@pharma.hr
} 
Previous research has shown that derivatization of well known NSAIDs to the corresponding hydroxamic acids yields substances with anti-inflammatory activity (3). Two of them, ibuproxam and oxamethacin, hydroxamic acid derivatives of ibuprofen and indomethacin, are efficient and internationally registered drugs (4). Since antioxidant activity of substances may have an important role in their anti-inflammatory and antiproliferative activities, the aim of this work was to determine the antioxidant properties of seven NSAID hydroxamic acids, derivatives of ibuprofen, fenoprofen, ketoprofen, indomethacin and diclofenac.

\section{EXPERIMENTAL}

\section{Materials}

Melting points were determined on a Stuart Melting Point Apparatus SMP3 (Stuart Barworld Scientific, UK) and were uncorrected. IR spectra were recorded on a FTIR Perkin Elmer Paragon 500 spectrometer (Perkin Elmer, UK). For absorbance measurements, a Lambda 25 (Perkin Elmer, UK) spectrophotometer was used. NSAID hydroxamic acids, namely $N$-hydroxy-2-(4-isobutyl-phenyl)propanamide (ibuproxam, 1), N-hydroxy-2-(3-phenoxy-phenyl)propanamide (2), $N$-hydroxy-2-(3-benzyl-phenyl)propanamide (3), N-hydroxy-2-[3-(hydroxy-phenyl-methyl)-phenyl]propanamide (4), 2-[1-(4-chloro-benzoyl)-5-methoxy-2-methyl-1H-indol-3-yl-]- $N$-hydroxy-acetamide (oxamethacin, 5), 2-[2-(2,6-dichloro-phenylamino)-phenyl]- $N$-hydroxy-acetamide (6) and 2-[2-(2,6-dichloro-phenylamino)-phenyl]-N-hydroxy- $N$-methyl-acetamide (7) (Fig. 1) were prepared following a previously published procedure $(5,6)$. All analytical and spectral data were in agreement with the previously published results. Butylated hydroxyanisol (BHA), 1,1-diphenyl-2-picrylhydrazyl (DPPH), $\beta$-carotene, linoleic acid and ferrozine were purchased from Sigma-Aldrich (USA). Other chemicals and solvents used were of analytical grade.

\section{Determination of the antioxidant activity using the $\beta$-carotene-linoleate assay}

The antioxidant activity of hydroxamic acids was evaluated using a $\beta$-carotene-linoleic acid model system (7). To $1 \mathrm{~mL}$ of $\beta$-carotene solution in chloroform $(0.2 \mu \mathrm{g} \mathrm{mL}-1)$, $20 \mathrm{mg}$ of linoleic acid and $200 \mathrm{mg}$ of Tween 40 were added. After removing chloroform in a rotary evaporator, $50 \mathrm{~mL}$ of aerated distilled water was added under vigorous stirring. Aliquots $(5 \mathrm{~mL})$ of thus obtained emulsion were transferred to a series of tubes containing $2 \mathrm{mg}$ of hydroxamic acid or $0.5 \mathrm{mg}$ of butylated hydroxyanisol (BHA, standard). The tube to which no antioxidant was added served as a negative control. The tubes were placed in a water bath at $50{ }^{\circ} \mathrm{C}$ for $2 \mathrm{~h}$. Absorbance of each sample was measured at $470 \mathrm{~nm}$ immediately after sample preparation and at 15-minutes intervals until the end of the experiment. A blank, devoid of $\beta$-carotene, was prepared for background subtraction. The antioxidant activity (ANT) was expressed as described in the literature (8) using the average bleaching rates of the negative control and antioxidant (hydroxamic acid or BHA), respectively. The rates of $\beta$-carotene bleaching for hydroxamic acids, BHA and water, were calculated according to first-order kinetics: 


$$
R=\frac{1}{t} \times \ln \frac{A_{0}}{A_{t}}
$$

where $t$ is the time in minutes, $A_{0}$ is the initial absorbance of the emulsion immediately after sample preparation $(t=0 \mathrm{~min})$ and $A_{\mathrm{t}}$ is the absorbance at three time intervals $(t=$ 15,30 or $45 \mathrm{~min}$ ). Based on the rates determined at three time intervals, the average rate of $\beta$-carotene degradation was calculated. Furthermore, the antioxidant activity was calculated from the absolute changes in absorbance at $t=60$ and $120 \mathrm{~min}\left(A A_{60}\right.$ and $A A_{120}$, respectively) (9). The results were normalized using both controls: negative and positive. The first should offer no protection against oxidation of $\beta$-carotene in emulsion, while the other should offer maximum protection during the assay. Accordingly, the antioxidant activity of the compounds was expressed as:

$$
A A=\left(1-\frac{A_{0}-A_{\mathrm{t}}}{\left(A_{0}^{\mathrm{W}}-A_{\mathrm{t}}^{\mathrm{W}}\right)+\left(A_{0}^{\mathrm{BHA}}-A_{\mathrm{t}}^{\mathrm{BHA}}\right)}\right) \times 100
$$

where $A_{0}$ is the absorbance of the tested compound solution at $0 \mathrm{~min}, A_{\mathrm{t}}$ is the absorbance at $t=60$ or $120 \mathrm{~min}, A_{0}^{\mathrm{W}}$ is the absorbance of the negative control at $0 \mathrm{~min}, A_{\mathrm{t}}^{\mathrm{W}}$ is the absorbance of the control at $t=60$ or $120 \mathrm{~min}, A_{0}^{\mathrm{BHA}}$ is the absorbance of BHA solution at $0 \mathrm{~min}$ and $A_{\mathrm{t}}^{\mathrm{BHA}}$ is the absorbance of BHA solution at $t=60$ or $120 \mathrm{~min}$.

\section{Free radical scavenging activity (RSA)}

The scavenging effect for DPPH radical was monitored according to the method of Yen and Chen (10) with minor modification. Briefly, $1.0 \mathrm{~mL}$ of hydroxamic acid solution $\left(\gamma=50-300 \mu \mathrm{g} \mathrm{mL}^{-1}\right)$ was added to $1.0 \mathrm{~mL}$ of DPPH ethanolic solution $(c=0.16 \mathrm{mmol}$ $\left.\mathrm{L}^{-1}\right)$. The mixtures were vortexed for $1 \mathrm{~min}$ and then left to stand at room temperature in the dark. After $30 \mathrm{~min}$, absorbance was read at $517 \mathrm{~nm}$. RSA for DPPH free radical was calculated using $A_{\text {control }}$ (absorbance of the control, solution to which no antioxidant was

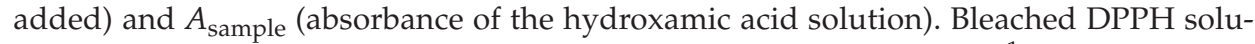
tion, prepared by adding $1.0 \mathrm{~mL}$ of DPPH solution $\left(c=0.16 \mathrm{mmol} \mathrm{L}^{-1}\right)$ to $1.0 \mathrm{~mL} \mathrm{BHA}$ solution $\left(\gamma=1 \mu \mathrm{g} \mathrm{mL}^{-1}\right)$, was used as a blank. DPPH radical scavenging activity was calculated as $E C_{50}$, the concentration that scavenges $50 \%$ of DPPH free radical and thus has $R S A=50 \%$. The antioxidant activity of BHA as standard reference was also assayed.

\section{Metal chelating activity (MChA)}

The chelating activity on $\mathrm{Fe}^{2+}$ was measured as reported by Decker and Welch (11). Hydroxamic acids (50-300 $\mu \mathrm{g})$ were added to $0.1 \mathrm{~mL}$ of $\mathrm{FeCl}_{2}$ solution $(c=2 \mathrm{mmol} \mathrm{L}-1)$. Reaction was initiated by the addition of $0.2 \mathrm{~mL}$ ferrozine solution $\left(c=5 \mathrm{mmol} \mathrm{L}^{-1}\right)$. The mixture was shaken vigorously and left standing at room temperature for $10 \mathrm{~min}$. After the reaction reached equilibrium, absorbance was determined at $562 \mathrm{~nm}$. MChA was calculated according to $A_{\text {control }}$ (absorbance of the negative control, solution to which no chelating agent was added) and $A_{\text {sample }}$ (absorbance of the hydroxamic acid solution). Metal chelating activity of hydroxamic acids was calculated as $E C_{50}$, the concentration 
that chelates $50 \%$ of $\mathrm{Fe}^{2+}$ ions and thus has $M C h A=50 \%$. Ethylenediaminetetraacetic acid (EDTA) was used as a standard.

\section{Statistical and $\log \mathrm{P}$ analysis}

All analyses were performed in triplicate. The data were recorded as mean \pm standard deviation. One-way analysis of variance was performed by ANOVA procedures using the GraphPad Prism version 3.00 for Windows (GraphPad Software, USA). Significant differences between means were determined by Tukey's tests. Unless otherwise specified, $p<0.05$ was regarded as statistically significant. $\log P$ values were calculated at the Virtual Computational Chemistry Laboratory (12).

\section{RESULTS AND DISCUSSION}

In the present work, antioxidant, radical scavenging and metal chelating activities of a series of NSAID hydroxamic acids, 1-7, were investigated (Fig. 1). Furthermore, relations between the antioxidant activity and wavenumber of the hydroxamic acid carbonyl band in IR spectra as well as $\log P$ were explored. NSAID hydroxamic acids 1, 2 and 5-7, derivatives of ibuprofen, fenoprofen, indomethacin and diclofenac, were synthesized by aminolysis of the corresponding NSAID benzotriazolide with hydroxylamine<smiles>CC(C)Cc1ccc(C(C)C(=O)NO)cc1</smiles>

N-hydroxy-2-(4-isobutyl-phenyl)propanamide (1)<smiles>CC(C(=O)NO)c1cccc(Cc2ccccc2)c1</smiles>

N-hydroxy-2-(3-benzyl-phenyl)propanamide (3)<smiles>COc1ccc2c(c1)c(CC(=O)NO)c(C)n2C(=O)c1ccc(Cl)cc1</smiles>

2-[1-(4-chloro-benzoyl)-5-methoxy-2-methyl$1 \mathrm{H}$-indol-3-yl]-N-hydroxy-acetamide (5)<smiles>CC(C(=O)NO)c1cccc(Oc2ccccc2)c1</smiles>

N-hydroxy-2-(3-phenoxy-phenyl)propanamide (2)<smiles>CC(C(=O)NO)c1cccc(C(O)c2ccccc2)c1</smiles>

N-hydroxy-2-[3-(hydroxy-phenyl-methyl)-phenyl]propanamide (4)<smiles>[R]N(O)C(=O)Cc1ccccc1Nc1c(Cl)cccc1Cl</smiles>

2-[2-(2,6-dichloro-phenylamino)-phenyl]$\mathrm{N}$-hydroxy-acetamide $(\mathrm{R}=\mathrm{H}, 6)$

2-[2-(2,6-dichloro-phenylamino)-phenyl]- $N$-hydroxy- $\mathrm{N}$-methyl-acetamide $\left(\mathrm{R}=\mathrm{CH}_{3}, 7\right)$

Fig. 1. Hydroxamic acids investigated in this study. 
or methylhydroxylamine, following our previously published method (5). Ketoprofen derivatives 3 and 4 were prepared by catalytic hydrogenation of $N$-benzyloxy-2-(3-benzoylphenyl)propanamide (6).

Antioxidant activity (ANT) was measured as the percentage of inhibition of lipid peroxidation in the $\beta$-carotene-linoleic acid system. According to the literature data (9), normalized antioxidant activity at 60 - and 120 -minutes of incubation $\left(A A_{60}\right.$ and $\left.A A_{120}\right)$ reflects the antioxidant activity more accurately than the ANT value.

All hydroxamic acids were able to reduce the rate of degradation of $\beta$-carotene (Table I) according to the pseudofirst order mechanism $\left(R^{2}>0.97\right)$. In all the assays performed, the investigated hydroxamic acids were significantly more active $(p<0.05)$ than the corresponding negative control. The strongest antioxidant among them was diclofenac $N$-methylhydroxamic acid $(7)(A N T=88.0 \pm 2.2 \%)$, whose activity did not significantly differ from the activity of BHA $(A N T=86.9 \pm 2.6 \%)$. The activity of compound 4 was significantly lower than the activity of the other tested substances (57.4 $\pm 6.1 \%)$.

The RSA of hydroxamic acids 1-7 was tested using the relatively stable free radical DPPH. This assay is frequently used because it has the advantage of being unaffected by certain side reactions, such as metal-ion chelation and enzyme inhibition. In its radical form, DPPH absorbs at $517 \mathrm{~nm}$, but the absorption decreases upon reaction with an antioxidant due to the formation of its non-radical form, DPPH-H. Transition metals (iron, copper, chromium, cobalt, vanadium, cadmium, nickel) can also be mediators in the formation of free radicals (e.g., Fenton chemistry). Therefore, metal chelating ability can also significantly contribute to the overall antioxidant activity. The radical scavenging activity and the metal chelating effects of NSAID hydroxamic acids were concentration dependent and increased with an increased amount of sample. The activities in both

Table I. IR carbonyl absorption bands and antioxidant activity of NSAID hydroxamic acids 1-7 in the $\beta$-carotene-linoleic acid system ${ }^{a}$

\begin{tabular}{|c|c|c|c|c|c|}
\hline Compd. & ANT $(\%)^{\mathrm{b}}$ & $A A_{60}(\%)^{\mathrm{c}}$ & $A A_{120}(\%)^{\mathrm{d}}$ & $v(\mathrm{CO})\left(\mathrm{cm}^{-1}\right)^{\mathrm{e}}$ & $\log P$ \\
\hline 1 & $82.3 \pm 4.5$ & $71.3 \pm 4.1$ & $68.3 \pm 3.2$ & 1631.9 & 2.77 \\
\hline 2 & $74.5 \pm 3.8$ & $70.6 \pm 2.0$ & $67.2 \pm 0.9$ & 1628.9 & 2.73 \\
\hline 3 & $76.8 \pm 3.2$ & $68.3 \pm 1.9$ & $66.1 \pm 1.9$ & 1634.5 & 3.10 \\
\hline 4 & $57.4 \pm 6.1$ & $49.9 \pm 4.6$ & $41.5 \pm 3.0$ & 1645.5 & 1.95 \\
\hline 5 & $71.5 \pm 1.4$ & $65.9 \pm 1.4$ & $63.8 \pm 1.0$ & 1635.0 & 3.22 \\
\hline 6 & $70.5 \pm 2.1$ & $65.4 \pm 1.0$ & $60.0 \pm 0.9$ & 1625.1 & 3.77 \\
\hline 7 & $88.0 \pm 2.2$ & $79.6 \pm 1.8$ & $76.7 \pm 1.2$ & 1614.7 & 3.53 \\
\hline BHA & $86.9 \pm 2.6$ & $80.2 \pm 1.0$ & $78.5 \pm 1.3$ & - & - \\
\hline Control $^{f}$ & - & $19.8 \pm 1.0$ & $21.5 \pm 1.3$ & - & - \\
\hline
\end{tabular}

a Mean $\pm \operatorname{SD}(n=3)$

b Antioxidant activity

c Normalized antioxidant activity at 60 -min of incubation

d Normalized antioxidant activity at 120-min of incubation

e IR spectra in accordance with the published data (5-6)

${ }^{\mathrm{f}}$ Reaction mixture without antioxidant 


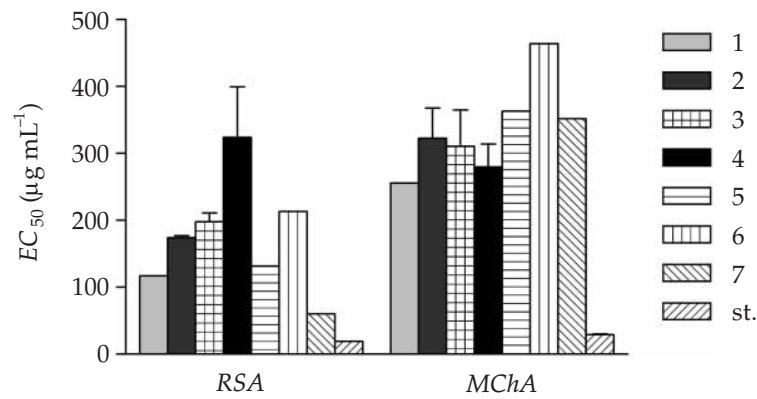

Fig. 2. Radical scavenging $(R S A)$ and metal chelating $(M C h A)$ activities of hydroxamic acids 1-7 presented as mean $E C_{50}$ values $\pm \mathrm{SD}$ $(n=3)$ and compared to the standard (st.): BHA for RSA and EDTA for $M C h A$.

tests were calculated as the concentrations exhibiting $50 \%$ of activity (Fig. 2). Hence, a lower $E C_{50}$ value indicated higher activity.

Hydroxamic acids 1-7 exhibited satisfactory DPPH free radical scavenging activity and metal chelating effect with ferrous ions. Among the tested NSAID hydroxamic acids, diclofenac $N$-methylhydroxamic acid (7) was a significantly better radical scavenger than the remaining derivatives $\left(E C_{50}=60.1 \mu \mathrm{g} \mathrm{mL}^{-1}\right)$ but still weaker than the standard substance, BHA $\left(E C_{50}=18.8 \mu \mathrm{g} \mathrm{mL}^{-1}\right)$. Compound 4 displayed the lowest activity $\left(E C_{50}\right.$ $=330 \mu \mathrm{g} \mathrm{mL}^{-1}$ ). These results fully correlate with the results of the $\beta$-carotene-linoleic acid model system. Since the least active compound has the lowest $\log P$, one can assume that the lipophilicity is important for the antioxidative activity. On the other hand, the best metal chelating activity was displayed by ibuprofen hydroxamic acid (1) $\left(E C_{50}=\right.$ $\left.255.6 \mu \mathrm{g} \mathrm{mL}^{-1}\right)$. The other compounds showed lower, but comparable activity. The activity of the positive control, EDTA, was higher than the activity of tested substances $\left(E C_{50}\right.$ $=29.1 \mu \mathrm{g} \mathrm{mL}^{-1}$ ).

Useful relationship exists between the chemical reactivity of the compounds bearing carbonyl functionality and their carbonyl stretching frequencies in the IR spectra. More reactive derivatives absorb at higher wavenumbers than the less reactive ones (13). On the other hand, the conjugation effect can cause the vibration to shift to a higher wavenumber, because the carbonyl group enters into resonance with the substituents that bear a lone pair of electrons (14). Thus, the relationship between the reactivity of hydroxamic acids and their activity in the performed tests might suggest a mechanism by which the hydroxamic acids react as antioxidants. The wavenumbers of carbonyl stretching absorptions of the investigated hydroxamic acids are listed in Table I. A negative correlation $\left(R^{2}=0.63\right)$ was found between the wavenumbers and the activity in the $\beta$-carotene-linoleate assay. The correlation increases if $A A_{60}$ and $A A_{120}$ are considered $\left(R^{2}=0.75\right.$ and 0.66 , respectively). On the other hand, a weak correlation between the wavenumbers of carbonyl groups and $E C_{50}$ in radical scavenging activity was observed $\left(R^{2}=0.58\right)$. Since the $E C_{50}$ value and the radical scavenging activity of a compound are inversely related, it can be concluded that the activity decreases with an increase in frequency of the carbonyl group stretching vibration. This might suggest that the resonance and its consequences (e.g., effect on acidity) might influence the antioxidant reactivity of investigated hydroxamic acids. On the other hand, there was no correlation between chelating activity $E C_{50}$ and the wavenumbers of stretching $\mathrm{C}=\mathrm{O}$ bands of hydroxamic acids. This might implicate that the mechanism for metal chelating activity differs from the mechanism by 
which the acids react in the former two assays. A weak correlation between $\log P$ and $E C_{50}$ of metal chelating activity was observed, implicating that the lipophilicity of investigated hydroxamic acids and their chelating abilities are inversely related $\left(R^{2}=0.61\right)$.

\section{CONCLUSIONS}

In the present study, hydroxamic acid derivatives of NSAIDs were found to possess significant antioxidant, radical scavenging and metal chelating activities, as determined by the $\beta$-carotene-linoleic acid model system, scavenging effect on the DPPH free radical as well as metal chelation effect in the $\mathrm{Fe}^{2+}$-ferrozin test system. It seems that a different mechanism is involved in the metal chelating activity than in the antioxidant and radical scavenging activities. The activity in the latter two tests may be connected with the extent of conjugation of the nitrogen lone electron pair with the carbonyl group. On the other hand, more hydrophilic substances were proven to be better iron chelators.

Acronyms. - AA - normalized antioxidant activity; ANT - antioxidant activity; BHA - butylated hydroxyanisol; DPPH - 1,1-diphenyl-2-picrylhydrazyl; $E C_{50}$ - concentration exhibiting $50 \%$ activity; EDTA - ethylenediaminetetraacetic acid; $M C h A$ - metal chelating activity; NSAID - nonsteroidal anti-inflammatory drug; RNS - reactive nitrogen species; ROS - reactive oxygen species; $R S A$ - radical scavenging activity.

Acknowledgements. - Support of this work by the Ministry of Science, Education and Sports of the Republic of Croatia (Projects 0006531 and 006-0000000-3216) is gratefully acknowledged.

\section{REFERENCES}

1. M. Valko, C. J. Rhodes, J. Moncol, M. Izakovic and M. Mazur, Free radicals, metals and antioxidants in oxidative stress-induced cancer, Chem-Biol. Interact. 160 (2006) 1-40; DOI: 10.1016/j.cbi. 2005.12.009.

2. M. E. Conner and M. B. Grisham, Inflammation, free radicals, and antioxidants, Nutrition $\mathbf{1 2}$ (1996) 274-277; DOI :10.1016/S0899-9007(96)00000-8.

3. R. R. Hamer, J. J. Tegeler, E. S. Kurtz, R. C. Allen, S. C. Bailey, M. E. Elliott, L. Hellyer, G. C. Helsley, P. Przekop, B. S. Freed, J. White and L. L. Martin, Dibenzoxepinone hydroxylamines and hydroxamic acids: dual inhibitors of cyclooxygenase and 5-lipoxygenase with potent topical anti-inflammatory activity, J. Med. Chem. 39 (1996) 246-252; DOI: 10.1021/jm950563z.

4. E. A. Kleemann, J. Engel, B. Kutscher and D. Reichert, Pharmaceutical Substances, Synthesis, Patents, Applications, Thieme, Stuttgart 2001.

5. Z. Rajić, I. Butula, B. Zorc, S. Kraljević Pavelić, K. Hock, K. Pavelić, L. Naesens, E. De Clercq, J. Balzarini, M. Przyborowska, T. Ossowski and M. Mintas, Cytostatic and antiviral evaluations of hydroxamic derivatives of some nonsteroidal anti-inflammatory drugs, Chem. Biol. Drug Des. 73 (2009) 328-338; DOI: 10.1111/j.1747-0285.2009.00774.x.

6. Z. Rajić, I. Perković, I. Butula, B. Zorc, D. Hadjipavlou-Litina, E. Pontiki, S. Pepeljnjak and I. Kosalec, Synthesis and biological evaluation of O-methyl and O-ethyl NSAID hydroxamic acids, J. Enz. Inhib. Med. Chem. 24 (2009), in press. 
7. H. E. Miller, Simplified method for the evaluation of antioxidants, J. Am. Oil Chem. Soc. 48 (1971) 91; DOI: 10.1007/BF02635693.

8. M. S. Al-Saikhan, L. R. Howard and J. C. Miller Jr., Antioxidant activity and total phenolics in different genotypes of potato (Solanum tuberosum, L.), J. Food Sci. 60 (1995) 341-343; DOI: 10.1111/ j.1365-2621.1995.tb05668.x.

9. R. Amarowicz, R. B. Pegg, P. Rahimi-Moghaddam, B. Barl and J. A. Weil, Free-radical scavenging capacity and antioxidant activity of selected plant species from the Canadian prairies, Food Chem. 84 (2004) 551-562; DOI: 10.1016/S0308-8146(03)00278-4.

10. G. C. Yen and H. Y. Chen, Antioxidant activity of various tea extracts in relation to their antimutagenicity, J. Agr. Food Chem. 43 (1995) 27-37; DOI: 10.1021/jf00049a007.

11. E. A. Decker and B. Welch, Role of feritin as lipid oxidation catalyst in muscle food, J. Agr. Food Chem. 36 (1990) 674-677; DOI: 10.1021/jf00093a019.

12. I. V. Tetko, J. Gasteiger, R. Todeschini, A. Mauri, D. Livingstone, P. Ertl, V. A. Palyulin, E. V. Radchenko, N. S. Zefirov, A. S. Makarenko, V. Y. Tanchuk and V. V. Prokopenko, Virtual computational chemistry laboratory - design and description, J. Comput. Aid. Mol. Des. 19 (2005) 453-463; DOI: 10.1007/s10822-005-8694-y; (http://www.vcclab.org, accessed date January 9, 2009).

13. I. Kalčić, M. Zovko, M. Jadrijević-Mladar Takač, B. Zorc and I. Butula, Synthesis and reactions of some azolecarboxylic acid derivatives, Croat. Chem. Acta 76 (2003) 217-228.

14. D. E. Lewis, Organic Chemistry, A Modern Perspective, Wm. C. Brown Publishers, Dubuque 1996.

\author{
$S A \check{Z} E T A K$
}

\title{
Antioksidativno djelovanje NSAID hidroksamskih kiselina
}

MARIJANA ZOVKO KONČIĆ, ZRINKA RAJIĆ, NEVA PETRIĆ i BRANKA ZORC

U radu je opisano antioksidativno djelovanje te sposobnost hvatanja slobodnih radikala i stvaranja kelata sedam hidroksamskih kiselina, derivata nesteroidnih protuupalnih lijekova ibuprofena, fenoprofena, ketoprofena, indometacina i diklofenaka. Najjače antioksidativno djelovanje i najjaču sposobnost hvatanja slobodnih radikala imala je $N$-metilhidroksamska kiselina diklofenaka $\left(A N T=88,0 \%\right.$ i $\left.E C_{50}=60,1 \mu \mathrm{g} \mathrm{mL}^{-1}\right)$. Vrijednosti za standardnu supstanciju, butilirani hidroksianisol, bile su: $A N T=86,9 \%$ i $E C_{50}=18,8 \mu \mathrm{g} \mathrm{mL}^{-1}$. Derivat ibuprofena bio je najjači kelator među ispitivanim hidroksamskim kiselinama $\left(E C_{50}=255,6 \mu \mathrm{g} \mathrm{mL}^{-1}\right)$, ali značajno slabiji od standardne supstancije, EDTA $\left(E C_{50}=29,1 \mu \mathrm{g} \mathrm{mL}^{-1}\right)$. Pretpostavlja se da su različiti mehanizmi uključeni u keliranje metala i antioksidativno djelovanje, odnosno hvatanje slobodnih radikala. Antioksidativno djelovanje i sposobnost hvatanja slobodnih radikala moglo bi biti povezano s konjugacijom slobodnog para elektrona na dušiku s karbonilnom skupinom. S druge strane, hidrofilnije supstancije pokazale su se kao jači kelatori iona željeza.

Ključne riječi: NSAID, hidroksamska kiselina, antioksidativno djelovanje, vezanje slobodnih radikala, sposobnost keliranja metala

Farmaceutsko-biokemijski fakultet, Zagreb 